\title{
Theoretical Aspects of Future Social Workers' Professional Self-Development
}

\author{
Karpenko Olena \\ Doctor of Pedagogical Sciences, Full Professor \\ Dragomanov National Pedagogical University (Kyiv, Ukraine) \\ Ostapchuk Victoria \\ Postgraduate \\ Dragomanov National Pedagogical University (Kyiv, Ukraine)
}

\begin{abstract}
The article defines and reveals the essence of the concepts "professional self-development", "selfdevelopment", presents the essence and ways of forming professional self-development in the future social worker; "self-education" as a component in the development of the future social worker is revealed and substantiated. The authors point out that the most important thing in personal development is consistency. The authors present the ways of forming self-development of future specialists' in the social sphere in the conditions of professional higher education institutions by means of extracurricular activities; theoretical directions of forming students' professional self-development by use of forms and methods of extracurricular activity are given.

Key words: students, social worker, institution of professional higher education, activity, extracurricular activity, self-development, professional self-development, self-analysis, self-assessment, selfeducation.
\end{abstract}

Актуальність дослідження. У контексті нашого дослідження ми визначаємо, що основним завданням формування професійно-особистісних якостей в особистості $€$ постійна робота над своїм самовдосконаленням, самопізнанням, а, також, готовність до безперервної самоосвіти та освіти своїх професійних якостей. Головними особливостями підготовки майбутніх соціальних працівників є зокрема сформувати професійну спрямованість яка б тісно відбувалася у формуванні особистості, а також безперервні процеси розвитку, самопізнання та саморозвитку.

Метою cmammi є аналіз змісту таких основних понять, як професійний саморозвиток, самопізнання у майбутніх соціальних працівників, самовиховання як складові майбутнього соціального працівника. Поняття «саморозвитку», зміст та його складові розглядалася в працях українськи та зарубіжних науковців: А. Грецова, Г. Артемчука, А. Маркової, С. Гончаренка, В. Кременя, В. Фокіної, А. Шаповалова та ін. Так, науковець А. Бистрюкова виокремила структуру професійного саморозвитку майбутнього спеціаліста, яка складалася з особистісних якостей та сукупності видів компетенції, розкриття яких відбувалося послідовно на етапі самовизначення студентом способу самоорганізації i потім забезпечування самореалізації спеціаліста як професіонала. А також вона виділила зовнішні та внутрішні 
чинники та сприяння у формуванні готовності до професійного саморозвитку майбутніх фахівців [9, с. 7-8; 8].

Динамізм соціально-економічних перетворень в нашому суспільстві визначається в даний час необхідністю розробки нових технологій, орієнтованих на розвиток в особистості активності, творчої індивідуальності, професійноособистісного потенціалу. Ці зміни в суспільстві викликають зміни і в системі освіти. Вони пов'язані, перш за все, з демократизацією і гуманізацією процесу навчання, освоєнням в практиці особистісно-орієнтованого, розвивального підходу, пошуком форм і методів педагогічної і психологічної допомоги та підтримки майбутніх соціальних працівників у їх розвитку і саморозвитку професійної майстерності.

Вітчизняна дослідниця Р. Вайнола визначила професійний розвиток особистості як неперервний процес залучення до професійної самореалізації, професії, відбувається вдосконалення особистості як суб'єкта певної професійної діяльності [1, с. 16].

Професійний саморозвиток розкривається лише тоді, коли особистість хоче володіти необхідними якостями. Вони можуть бути такі: професійні завдання, внутрішня мотивація, розуміння особливостей змісту саморозвитку, досягнення високих результатів, мотивація на себе. Саморозвиток може сформуватися досить швидко якщо розвивати основні складові такі як самовиховання та професійне пізнання.

В цілому, професійно-особистісний саморозвиток $\epsilon$ найважливішим елементом професійної діяльності соціального працівника. Професійний саморозвиток соціального працівника розглядається як цілісний багатокомпонентний та професійно-особистісний процес цілеспрямованої діяльності соціального працівника свідомо керувати своїм професійним розвитком, вибір цілей завдань, усвідомлення досвіду власної діяльності є засобом самопізнання.

Розкриваючи особливості професійно-особистісного саморозвитку студентів, можна визначити основні завдання, види діяльності, форми, методи стимулювання в майбутніх соціальних працівників в освітньому просторі. До завдань професійноособистісного саморозвитку відносяться: вироблення навичок і обгрунтування власних позицій та життєвих цінностей, сформування у студентів здатності мислити неординарно, уміння співпрацювати, вступати в партнерський діалог, виявляючи при цьому толерантність, доброзичливість, педагогічний такт тощо. 
Дана проблема є актуальною для вищої освіти, тому що заклад вищої освіти стає середовищем розвитку особистості для багатьох випускників шкіл, частка яких змирилася з беззмістовністю життя і незатребуваності їхніх сутнісних сил внаслідок обумовленого відходу освіти від мети виховання - формування унікальної, цілісної і вільної особистості, здатної усвідомлено створювати свою якість життя, вибудовувати і здійснювати власний життєвий шлях.

Зародження поняття «саморозвитку» почалося ще в Давній Греції, піфагорійці розглядали саморозвиток як свідомий процес. Сократ був одним із перших, хто розкрив проблему самопізнання та саморозвитку. Він вважав що людина $є$ центром наукового пізнання і тому метою самопізнання є розвиток задатків і почуттів, які спрямовані на розвиток добра та почуттів людини.

Проблематика саморозвитку на різних історичних етапах була розглянута та розкрита різними педагогічними школами і філософами в яких відображалися практики саморозвитку, досвід роботи вчених на різних історичних етапах розкрив соціальну та індивідуальну значущість самовиховання, самоосвіти, самовдосконалення. Мислителі протягом тривалого часу відтворювали у своїх концепціях усвідомлення сутнісних рис та форм саморозвитку особистості, спрямованість і залежність від домінуючих цінностей, створювалися також і релігійні доктрини (Аристотель, Конфуцій, Платон, Сенека, Сократ та ін.).

Отже, досліджуючи особливості саморозвитку (самовдосконалення, самоосвіта, самовиховання) особистості (що розглядалися в другій половині 21 століття), визначилися три основні напрямки: філософській, соціологічний та психолого-педагогічний, тому зауважимо, що значний внесок у розробку психологопедагогічного напрямку саморозвитку зробили О. Богданов, О. Ковальов, О. Кочетков, Ю. Самарін, В. Селіков, В. Сухомлинський, Л. Рувінський та ін.

У цілому саморозвиток соціального працівника як майбутнього спеціаліста розкривається за таких основних напрямках: розвиток здібностей, удосконалення психічно-особистісних процесів, підвищення почуття обов'язку, прояв почуття самовідповідальності, зміцнення професійної спрямованості, формуються необхідні якості такі як: зростання загальної зрілості та стійкості, зміцнення професійних якостей та готовності до майбутньої професійної діяльності соціального працівника $[4$, с. $75 ; 3 ; 4 ; 12 ; 13]$.

Основна роль значення самопізнання у професійній діяльності розглядалася та досліджувалася Т. Веретенко, Л. Мельничук, Л. Мітіної, М. Ткач, О.Степановою та 
ін. Самопізнання визначається як свідомий процес управління своїми особистісними якостями та здібностями.

Розглядаючи питання професійного самопізнання, вітчизняні вчені О. Степанова та М. Ткач стверджують, що самопізнання існує під впливом мотивацій, особливостями спілкування, і є своєрідною діяльністю [10, с. 37].

Загалом професійне самопізнання набуває особливої актуальності у період навчальної діяльності, а саме в даний період формуються мотиваційні цінності, когнітивні і рефлексивно-діяльнісні аспекти професійного саморозвитку особистості. Таким чином важливим завданням навчального закладу $\epsilon$ стимулювання особистісних потреб саморозвитку майбутніх соціальних працівників [7, с. 43].

Аналізуючи наукові дослідження, можна стверджувати, що процес професійного самопізнання є важливою складовою професійного саморозвитку, який вступає в процеси планування, реалізації планів та контролю. Через що, в процесі самопізнання, студент виокремлює свої здібності та можливості в обраному напрямку, а також має змогу підвищувати рівень свого професійного розвитку.

На думку I. Мельничук, професійне пізнання повинно здійснюватися в декількох напрямах: самопізнання себе в системі соціально-психологічних стосунках та навчально-діяльнісних стосунків, які передбачають самопізнання особистих якостей, що здійснюються шляхом самоспостереження, самоаналізу, поведінки, самоперевірки, самооцінки, вияву умінь якостей особистості, що забезпечує критичне ставлення майбутнього соціального працівника до своїх досягнень і недоліків. А мотиваційний компонент професійної моделі майбутнього фахівця соціальної сфери характеризується наявністю пізнавального інтересу до професії, пізнавальною активністю, що зумовлюється прагненням до виявлення таких професійних позицій, які можна і потрібно покращити, тобто, спрямованістю до саморозвитку [7 с. 99].

Висновок. Отже, професійний саморозвиток майбутнього соціального працівника - це комплексний підхід, у процесі якого майбутній соціальних працівників забезпечує високу якість професійного саморозвитку. Майбутній фахівець соціальної сфери має бути готовим до непередбачуваних ситуацій, кризових умов, уміти приймати правильне рішення в екстремальних умовах. Професійний саморозвиток соціального працівника розкривається як цілісний багатокомпонентний та професійно-особистісний процес цілеспрямованої діяльності соціального працівника, його здатності свідомо керувати своїм професійним розвитком, вибором цілей і завдань, усвідомленням досвіду власної діяльності як 
засобом самопізнання. Основним чинником цих вимог є професійний саморозвиток та самовиховання.

Слід зазначити, що саморозвиток та самовиховання $\epsilon$ складовими професійного саморозвитку у формуванні необхідної роботи над собою. Слід зауважити, що на етапі професійного самопізнання формується мотиваційний компонент професійної моделі майбутнього соціального працівника.

\section{References}

1. Vainola R. Kh. Pedahohichni zasady osobystisnoho rozvytku maibutnoho sotsialnoho pedahoha u protsesi profesiinoi pidhotovky [Pedagogical principles of personal development of the future social pedagogue in the process of professional training]: dys.... d-ra ped. nauk: 13.00.04 «Teoriia i metodyka profesiinoi osvity». Kyiv, 2009. 542 p.

2. Hlavatska O. L. Osnovy samovykhovannia osobystosti [Fundamentals of selfeducation of the individual] : navch.-metod. posib. Ternopil : Knyha, 2008. 206 p.

3. Karpenko O. H. Rol pedahohichnykh mozhlyvostei u protsesi hromadianskoho stanovlennia studentiv [The role of pedagogical opportunities in the process of civic formation of students]. Naukovyi chasopys Natsionalnoho ped. un-tu imeni MP Drahomanova. Seriia 11: Sotsialna robota. Sotsialna pedahohika. 2018. Issue 24 (2). Pp. 224-231.

4. Karpenko O. H. Teoretyko-metodolohichni pidkhody do pidhotovky maibutnikh sotsialnykh pratsivnykiv $u$ vyshchykh navchalnykh zakladakh [Theoretical and methodological approaches to the training of future social workers in higher education]. Naukovyi chasopys Natsionalnoho ped. un-tu imeni M. P. Drahomanova. Seriia 11 : Sotsialna robota. Sotsialna pedahohika: zb. nauk. prats. Kyiv : Vyd-vo NPU imeni M. P. Drahomanova, 2018. Issue 25. Pp. 73-79.

5. Karpenchuk S. H. Samovykhovannia osobystosti [Self-education of the individual] : navch. posib. Kyiv : IZMN,1998. 216 p.

6. Lozovyi V. O., Sidak L V. Samorozvytok osobystosti u filosofskii refleksii ta sotsialnii praktytsi [Self-development of personality in philosophical reflection and social practice] : monohrafiia. Kharkiv : Pravo, 2006. 256 p.

7. Melnychuk I. Teoriia i praktyka profesiinoi pidhotovky maibutnikh sotsialnykh pratsivnykiv zasobamy interaktyvnykh tekhnolohii [Theory and practice of professional training of future social workers by means of interactive technologies] : monohrafiia. Ternopil : Ekonomichna dumka, 2010. 326 p.

8. Petko L.V. Vyklyky XXI stolittia dlia osvitnoho prostoru Ukrainy. Naukovi pratsi ChNU: nauk. zhurnal [The challenges of educational space in the 21- ${ }^{\text {st }}$ century] / Chornom. Nats. un-t im. Petra Mohyly; red. Kol.: O.P.Meshchaninov (holova) [ta in.]. Mykolaiv: Vydvo ChNU imeni Petra Mohyly, 2017. Issue 303. Vol. 291. Pp. 10-14.

9. Tymoshenko N.Ie. Vstup do spetsialnosti: sotsialna robota. Modul 2 [Introduction to the specialty: social work] : navch. posib. Kyiv : Kyiv. un-t imeni Borysa Hrinchenka, 2014. 264 p.

10. Tkach M. V., Stepanova O. H. Pro sutnist profesiinoho samopiznannia [On the essence of professional self-knowledge]. URI : http://www.rusnauka.com. 
11. Trotsenko N. Ie. Profesiine samovdoskonalennia sotsialnykh pratsivnykiv $u$ resursnykh tsentrakh [Professional self-improvement of social workers in resource centers] : dys... kand. ped nauk : 13.00.05. Luhansk, 2011.243 p.

12. Karpenko O. G. The formation of professionalism in future social workers in the conditions of higher school // Geopolitical processes in the world today: Collection of scientific articles. - «East West» Association for Advanced Studies and Higher Education. Vienna (Austria). 2016. Pp. 301-304.

13. Pet'ko Lyudmila. Developing students' creativity in conditions of university // Research: tendencies and prospects: Collection of scientific articles. - Editorial Arane, S.A. de C.V., Mexico City, Mexico, 2017. Pp. 272-276.

\section{Translation of the Title, Abstract and References to the Author's Language}

\section{УДК 377.027.7}

Карпенко Олена, Остапчук Вікторія. Теоретичні аспекти професійного саморозвитку майбутніх соціальних працівників.

У статті визначено та розкрито суть понять «професійний саморозвиток», «саморозвиток», представлено сутність та шляхи формування професійного саморозвитку в майбутнього соціального працівника; розкривається та обгрунтовується «самовиховання» як складова розвитку майбутнього соціального працівника. Автором вивчаються питання саморозвитку майбутніх фахівців соціальної сфери в умовах закладу фахової передвищої освіти засобами позанавчальної діяльності; надаються теоретичні напрямки формування професійного саморозвитку у студентів шляхом використання форм та методик позанавчальної діяльності

Ключові слова: студенти, соціальний працівник, діяльність, позанавчальна діяльність, саморозвиток, професійний саморозвиток, самоаналіз, самооцінка, самовиховання.

\section{Лimepamypa}

1. Вайнола Р. Х. Педагогічні засади особистісного розвитку майбутнього соціального педагога у процесі професійної підготовки : дис. ... доктора пед. наук: 13.00 .04 «Теорія і методика професійної освіти». Київ, 2009. 542 с.

2. Главацька О. Л. Основи самовиховання особистості : навч.-метод. посіб. Тернопіль : Книга, 2008. $206 \mathrm{c}$.

3. Карпенко О.Г. Роль педагогічних можливостей у процесі громадянського становлення студентів. Науковий часопис Національного педагогічного університету імені МП Драгоманова. Серія 11: Соціальна робота. Соиіальна педагогіка.-2018. Вип. 24 (2). С. 224-231. URI : http://nbuv. gov. ua/UJRN/Nchnpu_011_2018_24\% 282\% $29 \_33$

4. Карпенко О.Г. Теоретико-методологічні підходи до підготовки майбутніх соціальних працівників у вищих навчальних закладах. Науковий часопис Національного педагогічного університету імені М. П. Драгоманова. Серія 11 : Сойіальна робота. Соціальна педагогіка : зб. наук. праць. Київ : Вид-во НПУ імені М. П. Драгоманова, 2018. Вип. 25. С. 73-79.

5. Карпенчук С. Г. Самовиховання особистост і: навч. посіб. Київ: IЗМН,1998. 216 с. 
6. Лозовий В О., Сідак Л. В. Саморозвиток особистості у філософській рефлексії та соціальній практиці: монографія. Харків : Право, 2006. 256 с.

7. Мельничук I. Теорія і практика професійної підготовки майбутніх соціальних працівників засобами інтерактивних технологій : монографія. Тернопіль : Економічна думка, 2010. 326 с.

8. Петько Л. В. Виклики XXI століття для освітнього простору України. Наукові праці [Чорноморського державного університету імені Петра Могили комплексу "КиєвоМогилянська академія"]. Серія : Педагогіка : наук. журн. / Чорном. держ. ун-т імені Петра Могили; ред. кол. : О. П. Мещанінов (голова) [та ін.]. Миколаїв : Вид-во ЧНУ імені Петра Могили, 2017. Т. 303. Вип. 291. С. 10-14.

9. Тимошенко Н. Є. Вступ до спеціальності : соціальна робота. Модуль 2 : навч. посіб. Київ : Київ. ун-т імені Бориса Грінченка, 2014. 264 с.

10. Ткач М. В., Степанова О. Г. Про сутність професійного самопізнання. URI :http://www.rusnauka.com.

11 Троценко Н. С. Професійне самовдосконалення соціальних працівників у ресурсних центрах: дис... канд. пед наук : 13.00.05. Луганськ, 2011. 243 с.

12. Karpenko O. G. The formation of professionalism in future social workers in the conditions of higher school // Geopolitical processes in the world today: Collection of scientific articles. - «East West» Association for Advanced Studies and Higher Education. Vienna (Austria). 2016. P. 301-304.

13. Pet'ko Lyudmila. Developing students' creativity in conditions of university // Research: tendencies and prospects: Collection of scientific articles. - Editorial Arane, S.A. de C.V., Mexico City, Mexico, 2017. P. 272-276. 